\title{
Alpha Granule
}

National Cancer Institute

\section{Source}

National Cancer Institute. Alpha Granule. NCI Thesaurus. Code C26618.

Granules found in several types of cells, especially platelets, where they are the most numerous type of granule; contain secretory proteins. 